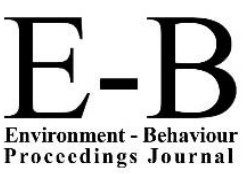

\section{AicE-Bs2016Edinburgh}

$7^{\text {th }}$ Asia-Pacific International Conference on Environment-Behaviour Studies, St Leonard Hall, Edinburgh University, United Kingdom, 27-30 July 2016

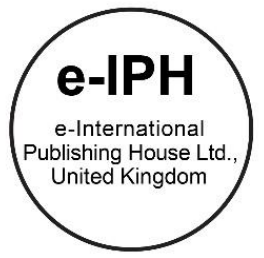

\title{
Solar Radiation and Urban Wind Effect on Urban Canyon in Hot, Humid Regions
}

\author{
Lin Yola *, Ho Chin Siong
}

Department of Built Environment, Faculty of Built Environment, Universiti Teknologi Malaysia, Skudai 81310, Malaysia

\begin{abstract}
Urban configuration modification is an efficient approach to mitigating Urban Heat Island effect. This study investigates the significant impact of solar radiation and urban wind on microclimate and thermal comfort in the different setting of urban canyon configuration. The Envi-met (V3.1 beta) simulation presents that East-West canyon direction received the worst level of air temperature and meant radiant temperature compared to when the canyon was directed perpendiculars to the wind direction (South East - North West). The finding scientifically demonstrates that in Kuala Lumpur context, with the slow urban wind speed influences, solar radiation plays the significant impact on the microclimate.

(C) 2016. The Authors. Published for AMER ABRA by e-International Publishing House, Ltd., UK. This is an open access article under the CC BYNC-ND license (http://creativecommons.org/licenses/by-nc-nd/4.0/).

Peer-review under responsibility of AMER (Association of Malaysian Environment-Behaviour Researchers), ABRA (Association of Behavioural Researchers on Asians) and CE-Bs (Centre for Environment-Behaviour Studies), Faculty of Architecture, Planning \& Surveying, Universiti Teknologi MARA, Malaysia.
\end{abstract}

Keywords: Solar radiation; urban wind; urban microclimate, urban simulation

\section{Introduction}

Urban Heat Island (UHI) is a current urban energy budget and other social-economic issues in a high-density urban area. As it is stressed to be an impact of urbanization, UHI raises significantly together with rapid new urban development (US Environmental Protection Agency, 2015 and $\mathrm{Ng}$, 2009). The warmer air temperature within the dense urban area over the surrounding rural area was reported up to $5.6^{\circ} \mathrm{C}$ and reaches the maximum intensity on three to five hour after sunset (Wang, Berardi, \& Akbari, 2016; Oke, 1978). As hot, humid regions receive the high intensity of solar radiation throughout the year, UHI effects play a significant role in their urban energy budget. Arifwidodo \& Chandrasiri (2015) reported that in $2012 \mathrm{UHI}$ in Bangkok as up to $7^{\circ} \mathrm{C}$ while Elsayed (2012) justified in his study that UHI of Kuala Lumpur was $1.5^{\circ} \mathrm{C}$ higher on 2004 compared to 1985 . This phenomenon is a threat to the city area since the warmer urban environment demands energy consumption for space cooling. Indoor and

* Corresponding author. Tel.: +60173004138

E-mail address: lin_yo_la@yahoo.com

2398-4287 @ 2016. The Authors. Published for AMER ABRA by e-International Publishing House, Ltd., UK. This is an open access article under the CC BY-NC-ND license (http://creativecommons.org/licenses/by-nc-nd/4.0/).

Peer-review under responsibility of AMER (Association of Malaysian Environment-Behaviour Researchers), ABRA (Association of Behavioural Researchers on Asians) and CE-Bs (Centre for Environment-Behaviour Studies), Faculty of Architecture, Planning \& Surveying, Universiti Teknologi MARA, Malaysia.

DOI: http://dx.doi.org/10.21834/e-bpj.v1i4.384 
outdoor environment are interrelated, therefore, both cause adjustment of UHI intensity and urban thermal comfort. The interrelation of the related variables indicates a direct impact on climate change (Sachindra, $\mathrm{Ng}$, Muthukumaran \& Perera, 2015), thermal comfort, energy demand, air pollution, and social issues (Arifwidodo \& Chandrasiri, 2015; Gartland, 2014; Santamouris et al., 2001; Oke, 1987). Human activities and modification of surface area determine the urban energy budget. US Environmental Protection Agency (2013) described that besides anthropogenic heat, urban heat circle significantly depends on the modification of urban surface (Fig 1). In this context, the configuration of the built up area and the open spaces are the major roles. Earlier work (Yola and Siong, 2013) and $\mathrm{Ng}$ (2009) justified that due to lacking of open space issue, urban development trend has no alternative but to extend vertically. The configuration of the dense urban area mainly influences the microclimate in between buildings. The issue is a shortwave radiation where it directly affects the daytime temperature and the indoor activities, especially in working places. Contrary, the ground surface emits the longwave radiation causes the UHI during the night time.

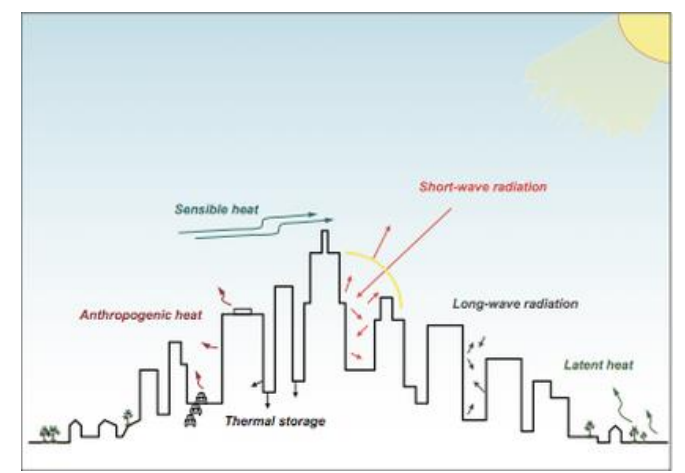

Fig. 1: Energy Budget System in Urban Area

Source: US Environmental Protection Agency, 2013

Yola and Siong (2015) pointed out in their earlier workthat the configuration of spaces and buildings in the dense urban area plays a significant role in the urban microclimate and outdoor activities. As high-density becomes a trend, the high-rise buildings shape the urban area into the giant wall that creates shaded spaces between buildings. Shaded areas generate a better thermal comfort in the hot and humid region. Better thermal comfort offers livable outdoor activities and better indoor thermal comfort. Studies also reported that indoor thermal comfort is strongly related to mitigation of cooling load (Abdallah, 2015; Chen, Sung, Chang, Chi, 2013; Givoni, 1998). Lundgren \& Kjellstrom (2013) justified that every $1^{\circ} \mathrm{C}$ outdoor temperature increase requires an $180 \mathrm{MW}$ base electricity load majorly required by air conditioning. It also reported that demand for the use of air conditioning which in buildings directly increases UHI in the urban area (Ohashi et al., 2007; Tremeac et al., 2012). The balance of the three considerations; microclimatic modification, thermal comfort and energy consumption create the 'climatic responsive urban configuration' in achieving city sustainability (Fig. 2). This framework illustrates the significance role of the urban configuration in corresponding to the best scenario of urban microclimate to achieve the maximum thermal comfort and energy conservation. Therefore, the aim of this study is to justify the significant impact of the modification of the urban canyon configuration on urban microclimate and thermal comfort. Specifically, the objective is to investigate the impact of urban canyon direction on solar radiation and urban wind. The finding of this study assists urban planners and designers to strategies the urban configuration to work with the urban microclimate. 


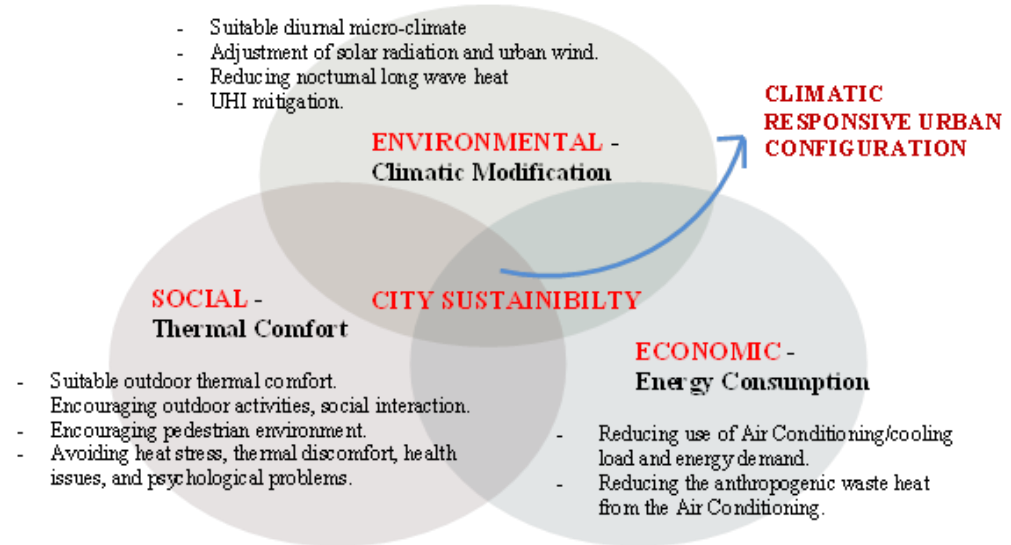

Fig. 2: Climatic responsive urban configuration framework.

\section{Urban canyon, solar radiation and urban wind}

There are ranges of design and planning strategies to mitigate the trend of temperature increase. The use of high albedo building materials and roof coating, involving green and water bodies and having more open surface instead of pavement and other cooling material are currently encouraged to reduce the heat and improve evaporation. However, urban planners and designers highlight that strategizing urban configuration is an effective solution to the temperature increase issue. Studies reported that urban configuration plays a significant impact on microclimate and outdoor thermal comfort (Achour-Younsi, \& Kharrat, 2015; Kariminia, Ahmad \& Saberi, 2015; Almhafdy, Ibrahim, Ahmad, \& Yahya, 2013). The urban canyon is the urban space configuration that is frequently investigated to measure urban microclimate and thermal comfort as the open space was obstructed by vertical surface of building walls. However, as discussed earlier, based on the argument on the factors that affects both urban microclimate and thermal comfort, the factors that affect both measures for different types of urban configurations become fundamental. In this scenario, the urban configuration is always examined and described by many factors that contribute to microclimate modification. Blazejczyk, Epstein, Jendritzky, Staiger, \& Tinz (2011) stressed the significant roles in urban canyon microclimate are; urban heat island, reduced wind speed, and maximum solar radiation penetration.

The urban surface energy system could clearly present from the heat cycle. The surface heat generated from the solar radiation and loses heat as illustrated in Fig. 1. Solar radiation (short wave) affects the daytime air temperature. Solar radiation partially converts into latent heat, while when it falls on the urban built-up surface, it absorbs and stores the heat day and night time (Givoni, 1998). This scenario will be worsening when the built up surface located within the enclosed spaces between buildings. This issue causes the air temperature increase in the night time in the urban area, which is the main contributor of UHI concentration. Oke (1981) formulated model (equation 1 \& 2) that present the maximum level of $\mathrm{UHI}$ in canyon space is formed by the relationship between height to width (H/W) aspect ratios and sky view factor (SVF). This result indicates that the configuration of building height and spaces between buildings determines the solar radiation penetration on the ground spaces. The open country space would significantly generate lesser UHI compared to deeper canyon space (Givoni, 1998). Meanwhile, the configuration of the urban roughness also impacts on the modification urban wind field on the whole scenario. As the radiation is absorbed and stored as heat in the urban surface, cooler urban wind eases the heat 
(Erell, Pearlmutter \& Wiliamson, 2010). When urban configuration creates the pattern of urban spaces, urban ventilation becomes a critical factor for creating the outdoor and indoor thermal comfort. In a hot and humid region, urban ventilation mainly reduces the heat stress over human body (Ng, 2009). Givoni \& Noguchi (2004) formed the thermal sensation of human affected by air temperature, solar radiation and wind speed. Both solar radiation and urban wind influence differently on different urban configuration, as the blocks could shade or block the open space from direct radiation or ventilation (Fig.3).

$$
\begin{aligned}
& \mathrm{dTmax}=7.45+3.97 * \ln (\mathrm{H} / \mathrm{W}) \\
& \mathrm{dTmax}=15.27-13.88{ }^{*} \mathrm{SVF}
\end{aligned}
$$

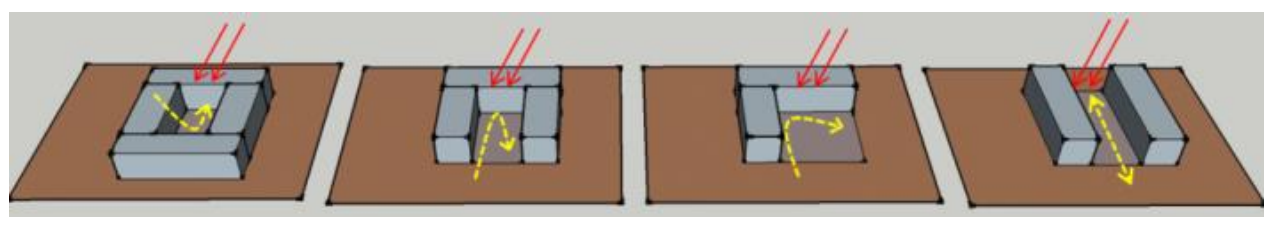

Fig. 3: Solar Radiation (marked as red) and Urban Wind (marked as yellow) Effect on Four Different Urban Configuration

As it concentrates on the urban canyon, the configuration of urban canyon in response to the radiation and urban wind exposure is the main concern of this paper. The apparent justification of the relationship of the urban microclimate or thermal comfort on the urban canyon with the key finding of aspect ratio and sky view factor was scientifically justified by Oke (1981), Givoni (1998), Ng (2009) and Erell, Pearlmutter, \& Williamson (2010). Recent studies describe further modifications of urban configuration that significantly affect urban microclimate and thermal comfort. One of them is canyon direction. Studies (Erell, Pearlmutter, \& Williamson, 2010; Ng, 2009; Givoni, 1998) highlight that urban canyon direction determines the behavior of solar to conducts the heat and the urban wind ventilates the canyon spaces. Therefore, as urban canyon direction takes major consideration in the planning and design process of urban configuration, strategizing urban canyon direction in response to the Kuala Lumpur microclimate context the focus of this study.

\section{Urban canyon simulation}

Hypothetical urban canyon configuration of symmetrical 40 meters height urban blocks were chosen as the case of this study (Fig. 4). This consideration is to maintain the constant urban configuration and unobstructed space to observe the urban microclimate. The height to width ratio $(\mathrm{H} / \mathrm{W})$ of the hypothetical Canyon is 2:1 with 6:19 built up to open space ratio. The directions of the urban canyon were limited to four scenarios; canyon direction according to radiation exposures of four cardinal directions (East-West and South-North) and parallel with and perpendicular to the urban wind (Fig.5). ENVI-met V3.1, 3D microclimate simulation software was used to conduct the simulation as it reported that the ENVI-met is a suitable tool to perform the quantitative analysis of this study, as also highlighted in previous literature (Yola and Siong, 2014). The data simulated through the receptor that consistently positioned in the middle of the canyon at the 0 -meter position. The microclimates data was taken every sixty minutes for 24 hours which were limited to the direct radiation, diffuse radiation, humidity, velocity, air temperature (Ta) and Meant 
Radiant Temperature (Tmrt). The urban canyon location was set in Kuala Lumpur city center $\left(3^{\circ} 8^{\prime} \mathrm{N} 101^{\circ} 41^{\prime} \mathrm{E}\right)$ on 5th August 2014. The sun path of this date illustrated in Fig.6.

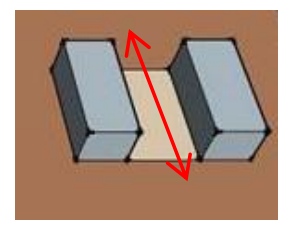

Fig. 4: Hypothetical Urban Canyon Configuration

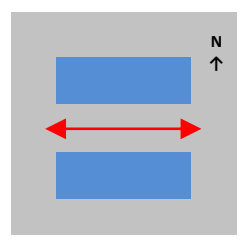

East-West Canyon Direction

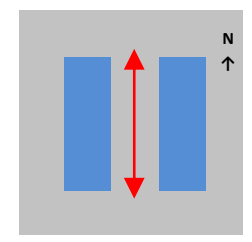

South-North Canyon Direction

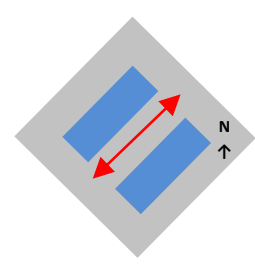

Canyon Parallel with the Wind Direction

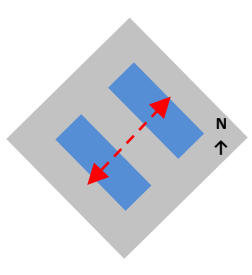

Canyon Perpendicular to the Wind Direction

Fig. 5: Urban Canyon Direction According to Radiation Exposure (left) and According to Wind Direction (right)

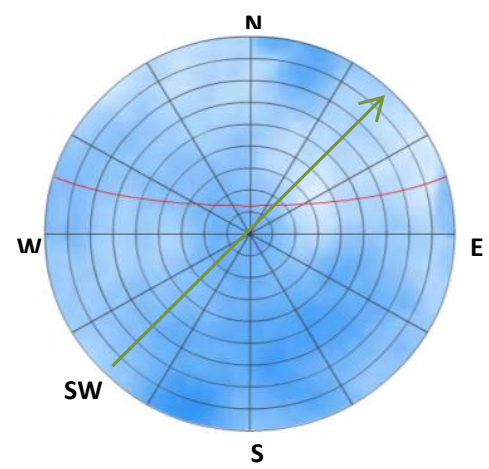

Fig. 6: Sun Path Marked on Red and Urban Wind Direction Marked on Green on 5 August 2015 at Study Area Adapted from Photovoltaic Education Network, 2015

The input data in ENVI-met based on 2014 Kuala Lumpur weather data. The urban wind speed was $1.6 \mathrm{~m} / \mathrm{s}$ with 225 South-West Direction. The relative humidity was at $83 \%$, and the initial temperature was at $300 \mathrm{~K}$. The heat transmission of the wall was $1.94 \mathrm{~W} / \mathrm{m}^{2} \mathrm{~K}$ and heat transmission of the roof was $6 \mathrm{~W} / \mathrm{m}^{2} \mathrm{~K}$, and the albedo wall was 0.3 while albedo roof was 0.5 . The data presented through comparison of day-time and night-time, as well as the mean of each variable to observe the effect of the four scenarios of canyon direction. 


\section{Result and discussion}

The microclimate results are presented by comparing the impact of solar radiation and urban wind. Thus, direct and diffuse solar radiations, whereby humidity and velocity are justified to examine the urban wind effects. Air temperature $(\mathrm{Ta})$ is to show the urban micro-climate while Meant Radiant Temperature (Tmrt) represents the outdoor thermal comfort. Direct radiation (Table 1) was recorded high reading for Canyon directed to East-West and parallel with the urban wind $\left(591.76 \mathrm{~W} / \mathrm{m}^{2}\right.$ and $\left.244.37 \mathrm{~W} / \mathrm{m}^{2}\right)$. While diffuse radiation behaves differently (Table 2). Canyon perpendicular to the urban wind together with the South-North direction $\left(33.29 \mathrm{~W} / \mathrm{m}^{2}\right)$ was higher than EastWest direction $\left(33.25 \mathrm{~W} / \mathrm{m}^{2}\right)$ and parallel with the urban wind $\left(33.12 \mathrm{~W} / \mathrm{m}^{2}\right)$. The similar trend also indicated for both humidity and air velocity (Table 3 and Table 4). The humidity was high when the canyon was directed to SouthNorth $(69.64 \%)$ and perpendicular to the urban wind $(69.54 \%)$. Lastly, the highest velocity was found where Canyon was directed perpendicular to the urban wind $(1.97 \mathrm{~m} / \mathrm{s})$ followed by South - North direction $(1.52 \mathrm{~m} / \mathrm{s})$.

Table 1: Direct radiation

\begin{tabular}{l|l}
\hline Canyon direction & Direct radiation $\left(\mathrm{W} / \mathrm{m}^{2}\right)$ \\
\hline Perpendicular to the urban wind & 164.21 \\
\hline Parallel with the urban wind & 244.37 \\
\hline East-West & 591.76 \\
\hline South-North & 164.92 \\
\hline
\end{tabular}

Table 2: Diffuse radiation

\begin{tabular}{l|l}
\hline Canyon direction & Direct radiation $\left(\mathrm{W} / \mathrm{m}^{2}\right)$ \\
\hline Perpendicular to the urban wind & 33.29 \\
\hline Parallel with the urban wind & 33.12 \\
\hline East-West & 33.25 \\
\hline South-North & 33.29 \\
\hline
\end{tabular}


Table 3: Humidity

\begin{tabular}{l|l|l|l}
\hline Canyon direction & Day time (\%) & Night time (\%) & Mean (\%) \\
\hline Perpendicular to the urban wind & 71.39 & 67.69 & 69.54 \\
\hline Parallel with the urban wind & 74.00 & 79.07 & 76.53 \\
\hline East-West & 69.37 & 67.78 & 68.58 \\
\hline South-North & 70.52 & 68.75 & 69.64 \\
\hline
\end{tabular}

Table 4: Velocity

\begin{tabular}{l|l|l|l}
\hline Canyon direction & Day time $(\mathrm{m} / \mathrm{s})$ & Night time $(\mathrm{m} / \mathrm{s})$ & Mean $(\mathrm{m} / \mathrm{s})$ \\
\hline Perpendicular to the urban wind & 1.75 & 2.19 & 1.97 \\
\hline Parallel with the urban wind & 0.06 & 0.07 & 0.06 \\
\hline East-West & 1.21 & 1.56 & 1.39 \\
\hline South-North & 1.29 & 1.76 & 1.52 \\
\hline
\end{tabular}

The air temperature (Ta) and Meant Radiant Temperature (Tmrt) of urban canyon directed to the four different scenarios were tested to identify how the four discussed components of urban microclimate affect UHI and urban thermal comfort. The results illustrated in Table 5 and Table 6 . The results show that the highest air temperature (Ta) identified when canyon as oriented to East-West $\left(27.29^{\circ} \mathrm{C}\right)$, follows by when the canyon was directed parallel to the urban wind $\left(27.16^{\circ} \mathrm{C}\right)$. The same trend presented for Meant Radiant Temperature (Tmrt). The highest indicated when the canyon directed to East-West $\left(48.87^{\circ} \mathrm{C}\right)$ and when the canyon was directed parallel to the wind $\left(29.71^{\circ} \mathrm{C}\right)$.

Table 5: Air temperature

\begin{tabular}{l|l|l|l}
\hline Canyon direction & Day time $\left({ }^{\circ} \mathrm{C}\right)$ & Night time $\left({ }^{\circ} \mathrm{C}\right)$ & Mean $\left({ }^{\circ} \mathrm{C}\right)$ \\
\hline Perpendicular to the urban wind & 28.57 & 24.90 & 26.73 \\
\hline Parallel with the urban wind & 28.57 & 25.75 & 27.16 \\
\hline East-West & 28.78 & 25.81 & 27.29 \\
\hline South-North & & & 26.97 \\
\hline
\end{tabular}


Table 6: Meant Radiant Temperature (Tmrt)

\begin{tabular}{l|l|l|l}
\hline Canyon direction & Day time $\left({ }^{\circ} \mathrm{C}\right)$ & Night time $\left({ }^{\circ} \mathrm{C}\right)$ & Mean $\left({ }^{\circ} \mathrm{C}\right)$ \\
\hline Perpendicular to the urban wind & 37.25 & 17.58 & 27.42 \\
\hline Parallel with the urban wind & 40.35 & 19.07 & 29.71 \\
\hline East-West & 58.96 & 38.78 & 48.87 \\
\hline South-North & 36.17 & 18.03 & 27.10 \\
\hline
\end{tabular}

The surface image of both air temperature (Ta) and Mean Radiant Temperature (Tmrt) illustrated in Fig. 7 to Fig.8. The images generated for only the two scenarios with the highest readings to show the significant impact on the ground surface area. The images were the $x$-y section at 0 -meter on $14.00 \mathrm{pm}$ where the radiation was of the maximum intensity. Besides showing the difference between East-West and parallel with the urban wind direction, the images are also presenting the patterns of both air temperature ( $\mathrm{Ta}$ ) and Mean Radiant Temperature (Tmrt).
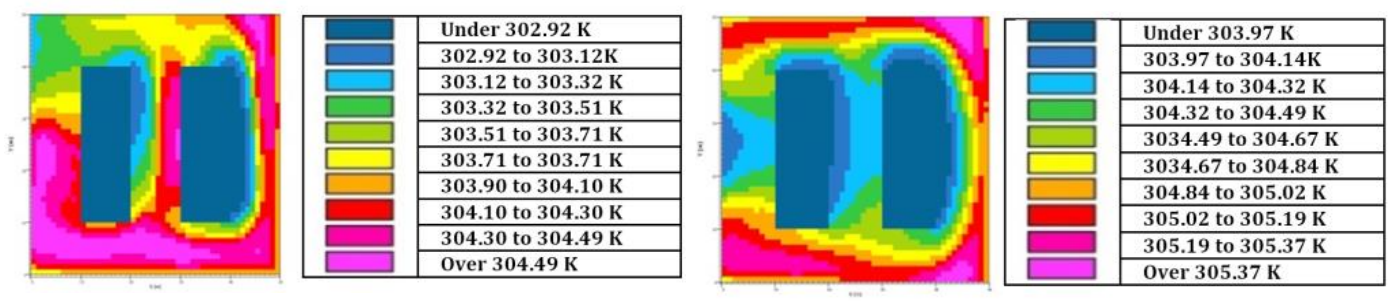

Fig.7: x-y Air Temperature (Ta) Image on East-West Canyon Direction (left) and when Canyon Parallel with Urban Wind Direction (right) at 0 meter, $14.00 \mathrm{pm}$


Fig.8: $x$-y Mean Radiant Temperature (Tmrt) Image on East-West Canyon Direction (left) and when Canyon Parallel with Urban Wind Direction (right) at 0 meter, $14.00 \mathrm{pm}$ 
The results show that East - West Canyon direction has the highest air temperature (Ta) as well as Mean Radiant Temperature (Tmrt) compared to South - North. This finding is because of the canyon was exposed to direct solar radiation along East-West sun path. When the canyon influenced by urban wind direction, both air temperature and (Ta) Mean Radiant Temperature (Tmrt) of the canyon direction parallel with the wind was higher over perpendicular to the urban wind. It is a questioned phenomenon as urban wind flow should reduce the heat frequently at urban canyon as this urban canyon configuration shape an urban wind tunnel between the buildings. It could explain that the urban wind speed at 0-meter level or ground surface could reach the low speed at parallel with the urban wind urban canyon direction. Moreover, the urban wind speed in Kuala Lumpur city specifically to some extent in high-density development area could reach extremely low. The whole scenario shows that with the urban wind effect, the air temperature (Ta) and Mean Radiant Temperature (Tmrt) could reach the maximum level when the canyon direction closed to East-West where the direct solar radiation is maximum.

\section{Conclusion}

Urban configuration emphasized as one of passive energy strategies to maximize urban heat island mitigation. This study brings up the need for spaces between the urban blocks in creating the outdoor thermal comfort for city dwellers. In achieving this purpose, this study by examining urban canyon alternatives scenarios as the chosen urban configuration to present both urban microclimate and thermal comfort. The results show that in Kuala Lumpur context, the solar radiation exposure of urban canyon indicates higher both air temperature $(\mathrm{Ta})$ and Meant Radiant Temperature (Tmrt) over urban wind exposure. This finding is due to high intensity of solar radiation compared to the impact of slow urban wind speed in Kuala Lumpur city context. This finding could be used to recommend urban planners and designers to strategize the urban canyon to suit avoiding the East-West direction. This strategy aims to minimize urban air temperature increase as well as to achieve maximum thermal comfort within the outdoor space between the urban blocks.

\section{References}

Abdallah, A. S. H. (2015). The influence of urban geometry on thermal comfort and energy consumption in residential building of hot arid climate, Assiut, Egypt. Procedia Engineering, 121, 158-166. doi:10.1016/j.proeng.2015.08.1043.

Achour-Younsi, S., \& Kharrat, F. (2016). Outdoor thermal comfort: Impact of the geometry of an urban street canyon in a Mediterranean Subtropical climate - case study Tunis, Tunisia. Procedia - Social and Behavioral Sciences, 216, 689-700. doi:10.1016/j.sbspro.2015.12.062.

Almhafdy, A., Ibrahim, N., Ahmad, S. S., \& Yahya, J. (2013). Analysis of the courtyard functions and its design variants in the Malaysian hospitals. Procedia - Social and Behavioral Sciences, 105, 171-182. doi:10.1016/j.sbspro.2013.11.018.

Arifwidodo, S., \& Chandrasiri, O. (2015). Urban heat island and household energy consumption in Bangkok, Thailand. Energy Procedia, 79, 189194. doi:10.1016/j.egypro.2015.11.461.

Blazejczyk, K., Epstein, Y., Jendritzky, G., Staiger, H., \& Tinz, B. (2011). Comparison of UTCI to selected thermal indices. International Journal of Biometeorology, 56(3), 515-535. doi:10.1007/s00484-011-0453-2.

Chen, R., Sung, W.-P., Chang, H.-C., \& Chi, Y.-R. (2013). Applying outdoor environment to develop health, comfort, and energy saving in the office in hot-humid climate. The Scientific World Journal, 2013, 1-8. doi:10.1155/2013/367283.

Elsayed, I. (2012). A study on the urban heat island of the city of Kuala Lumpur, Malaysia. Journal of King Abdulaziz University-Meteorology, Environment and Arid Land Agriculture Sciences, 23(2), 121-134. doi:10.4197/met.23-2-8.

Emmanuel, R., Rosenlund, H., \& Johansson, E. (2007). Urban shading-a design option for the tropics? A study in Colombo, Sri Lanka. International Journal of Climatology, 27(14), 1995-2004. doi:10.1002/joc.1609. 
Erell, E., Pearlmutter, D., \& Williamson, T. (2010). Urban Microclimate: Designing the spaces between buildings. Washington, DC: Earthscan / James \& James.

Gartland, L. (2014). Heat islands: Understanding and mitigating heat in urban areas. Los Angeles, CA, United States: Earthscan Publications.

Givoni, B. (1998). Climate considerations in building and urban design. New York: Van Nostrand Reinhold.

Givoni, B. \& Noguchi. (2004). Outdoor Comfort Responses of Japanese Person's. In Proceedings of the American Solar Energy Society: National Solar Energy Conference 2004, 9-14 July, Portland, OR.

Kariminia, S., Ahmad, S. S., \& Saberi, A. (2015). Microclimatic conditions of an urban square: Role of built environment and geometry. Procedia Social and Behavioral Sciences, 170, 718-727. doi:10.1016/j.sbspro.2015.01.074.

Lundgren, K., \& Kjellstrom, T. (2013). Sustainability challenges from climate change and air conditioning use in urban areas. Sustainability, 5(7), 3116-3128. doi:10.3390/su5073116.

$\mathrm{Ng}$, E. (Ed.). (2009). Designing high-density cities: For social and environmental sustainability. London: Earthscan Publications.

Ohashi, Y., Genchi, Y., Kondo, H., Kikegawa, Y., Yoshikado, H., \& Hirano, Y. (2007). Influence of air-conditioning waste heat on air temperature in Tokyo during summer: Numerical experiments using an urban canopy model coupled with a building energy model. Journal of Applied Meteorology and Climatology, 46(1), 66-81. doi:10.1175/jam2441.1.

Oke, T. R. (1987). Boundary Layer Climates. (2nd ed.).: Routledge.

Oke, T. R. (1981). Canyon Geometry and the Nocturnal Urban Heat Island: Comparison of Scale Model and Field Observations. Journal Climatology, 1, 237-254.

Photovoltaic Education Network. (2015). Sun Position Calculator. Retrieved July 2015, from www.pveducation.org.

Sachindra, D. A., Ng, A. W. M., Muthukumaran, S., \& Perera, B. J. C. (2015). Impact of climate change on urban heat island effect and extreme temperatures: A case-study. Quarterly Journal of the Royal Meteorological Society, 142(694), 172-186. doi:10.1002/qj.2642.

Santamouris, M., Papanikolaou, N., Livada, I., Koronakis, I., Georgakis, C., Argiriou, A., \& Assimakopoulos, D. N. (2001). On the impact of urban climate on the energy consumption of buildings. Solar Energy, 70(3), 201-216. doi:10.1016/s0038-092x(00)00095-5.

Tremeac, B., Bousquet, P., de Munck, C., Pigeon, G., Masson, V., Marchadier, C., ... Meunier, F. (2012). Influence of air conditioning management on heat island in Paris air street temperatures. Applied Energy, 95, 102-110. doi:10.1016/j.apenergy.2012.02.015.

US Environmental Protection Agency (EPA). (2013). Climate Protection Partnership Division US. Reducing Urban Heat Islands: Compendium of Strategies, Urban Heat Island Basics.

United States Environmental Protection Agency. (2015). State and Local and Energy Program. US EPA 2015.

Wang, Y., Berardi, U., \& Akbari, H. (2016). Comparing the effects of urban heat island mitigation strategies for Toronto, Canada. Energy and Buildings, 114, 2-19. doi:10.1016/j.enbuild.2015.06.046.

Yola, L. and Siong, H. C. (2015). Urban Configuration Effect on Urban Microclimate and Thermal Comfort. 9th South East Asian Technical University Consortium (SEATUC) Symposium 2015.

Yola, L. and Siong, H. C. (2014). Modeling and Simulation Approach of Assessing Urban Form (A Review). International Journal of Emerging Trends in Commerce, Humanities and Social Science (CEHSS).

Yola, L. and Siong, H. C. (2013). Understanding Vertical City Concept. 4th International Graduate Conference on Engineering, Science, and Humanities. Universiti Teknologi Malaysia. 